\title{
PENGARUH FAKTOR-FAKTOR YANG DAPAT MEMOTIVASI \\ MAHASISWA BERKEINGINAN WIRAUSAHA
}

\author{
Willyanto Kartiko Kusumo, SE., M.Si., CFA, Drs. Wawan Setiawan, MM. \\ Fakultas Ekonomi Universitas Semarang
}

\begin{abstract}
ABSTRACK
The purpose of this study was to analyze the influence of self efficacy, tolerance of risk, freedom in work, need for achievement, and readiness to desire instrumentation Gunadarma University students to be entrepreneurs. Type of data used is the primary data. The research method used was survey by an inductive analysis approach to look ways that generally used in examining the factors that influence the willingness of students to become entrepreneurs. Methods of collecting data is using a questionnaire with 100 people as respondents. The sampling technique used was simple random technique (Random Sampling Method). Data were processed and analyzed using SPSS application assistance. Analysis tools used in this study is to test the validity, reliability, multiple regression liniear, pearson correlation, and independent sample t test. These results indicate that the variable of self success, Freedom in Works, and the Necessity of achievement which is a dominant variable in influencing the desire of Semarang University Students to become an entrepreneur.
\end{abstract}

Keywords : self success,Tolerance of risk, Freedom in the Work, Need Achievement, Readiness Instrumentation, Desire Being an Entrepreneur

\begin{abstract}
ABSTRAK
Tujuan dari penelitian ini adalah untuk menganalisis pengaruh keberhasilan diri, toleransi akan resiko, kebebasan dalam bekerja, kebutuhan akan prestasi, dan kesiapan instrumentasi terhadap keinginan mahasiswa Universitas Gunadarma menjadi wirausaha. Jenis data yang digunakan merupakan data primer. Metode penelitian adalah survei dengan pendekatan analisis induktif untuk melihat cara-cara yang di pakai secara umum dalam menguji faktor-faktor yang mempengaruhi keinginan mahasiswa menjadi wirausahawan. Metode pengumpulan data menggunakan kuesioner dengan jumlah responden sebanyak 100 orang. Teknik pengambilan sampel yang digunakan adalah teknik acak sederhana (Random Sampling Method). Data diolah dan dianalisis dengan menggunakan bantuan aplikasi SPSS. Alat analisis yang digunakan dalam penelitian ini adalah uji validitas, reliabilitas, dan regresi liniear berganda. Hasil penelitian ini menunjukkan bahwa variabel Keberhasilan Diri, Kebebasan Dalam Bekerja, dan Kebutuhan Akan Prestasi yang merupakan variabel dominan dalam mempengaruhi Keinginan Mahasiswa Universitas SemarangMenjadi Wirausahawan.
\end{abstract}

Kata kunci : Keberhasilan Diri, Toleransi Akan Resiko, Kebebasan Dalam Bekerja, Kebutuhan Akan Prestasi, Kesiapan Instrumentasi, Keinginan Menjadi Wirausaha. 


\section{PENDAHULUAN}

Pengangguran di Indonesia semakin hari semakin meningkat jumlahnya seiring dengan berjalannya waktu. Para pencari kerja baik yang mempunyai gelar sarjana ataupun tidak harus bersaing untuk mendapatkan pekerjaan pada lapangan kerja yang terbatas. Adapun penyebab masalah pengangguran terdidik adalah banyaknya sarjana bertujuan hanya mencari pekerjaan, bukan menciptakan lapangan pekerjaan. padahal menjadi seorang wirausaha merupakan salah satu pendukung yang menentukan maju mundurnya perekonomian, karena bidang wirausaha mempunyai kebebasan untuk berkarya dan mandiri. Wirausaha inilah yang mampu menciptakan lapangan kerja baru agar mampu menyerap tenaga kerja.

Kecenderungan yang terjadi pada mahasiswa-mahasiswa yang duduk di perguruan tinggi saat ini adalah kebanyakan dari mereka lebih menginginkan pekerjaan yang mapan dengan mendapatkan status yang terhormat dan banyak menghasilkan pendapatan setelah menyelesaikan pendidikannya. kecenderungan bahwa sebagian besar mahasiswa, termasuk mahasiswa tingkat akhir, serta para sarjana yang baru saja lulus tidak memiliki rencana berwirausaha. Umumnya mereka lebih memilih untuk menjadi seorang pekerja pada perusahaan-perusahaan besar maupun instansi pemerintah (menjadi PNS) guna menjamin masa depan mereka. Oleh karena itu, para sarjana lulusan perguruan tinggi perlu diarahkan dan didukung untuk tidak hanya berorientasi sebagai pencari kerja (job seeker) namun dapat dan siap menjadi pencipta pekerjaan (job creator) juga. hal utama yang menyebabkan seseorang melakukan kegiatan wirausaha adalah karena adanya keinginan untuk berwirausaha.

Adi Susanto (2000) mengemukakan, beberapa motivasi yang dapat mendorong seseorang untuk menjadi wirausaha yaitu keinginan merasakan pekerjaan bebas, keberhasilan diri yang dicapai, dan toleransi akan adanya resiko. Maksudnya disini adalah Kebebasan dalam bekerja merupakan sebuah model kerja dimana seseorang melakukan pekerjaan sedikit tetapi memperoleh hasil yang besar. Berangkat kerja tanpa terikat pada aturan atau jam kerja formal, atau berbisnis jarang-jarang tetapi sekali mendapat untung, apalagi untungnya cukup untuk dinikmati berbulan-bulan atau cukup untuk sekian minggu kedepan. Sedangkan Keberhasilan diri yang dicapai merupakan pencapaian tujuan kerja yang diharapkan, yang meliputi kepuasan dalam bekerja dan kenyamanan kerja. dan Toleransi akan resiko, merupakan seberapa besar kemampuan dan kreativitas seseorang dalam menyelesaikan besar kecilnya suatu resiko yang diambil untuk mendapatkan penghasilan yang diharapkan. Semakin besar seseorang pada kemampuan diri sendiri, semakin besar pula keyakinannya terhadap kesanggupan mendapatkan hasil dari keputusannya dan semakin besar keyakinannya untuk mencoba apa yang dilihat orang lain beresiko.

Selain itu Wirausahawan harus dapat menentukan jumlah modal yang diperlukan guna memulai sebuah usaha, seorang wirausahawan pertama-tama harus menentukan jumlah minimum dari masing-masing sumber daya yang diperlukan. Sebagian sumber daya dibutuhkan dalam tingkat kuantitas dan kualitas yang lebih tinggi dari dibandingkan dengan sebagian lainnya (Susanto, 2009:11).

Ketersediaan informasi usaha juga merupakan faktor penting yang mendorong keinginan seseorang untuk membuka usaha baru dan faktor kritikal bagi pertumbuhan dan keberlangsungan usaha (Indarti, 2008). Campur tangan orang lain dapat menentukan keberhasilan atau kegagalan seseorang dalam dunia bisnis. Relasi bisnis memiliki prinsip berbanding lurus, artinya semakin banyak jumlah relasi bisnis, semakin cepat seseorang mencapai sukses dalam berusaha, begitu juga sebaliknya (Sudjatmoko, 2009:25).

Ketersediaan modal, ketersediaan informasi, dan ketersediaan relasi bisnis disebut kesiapan instrumentasi seorang wirausahawan (Indarti, 2008). Kesiapan 
instrumentasi tersebut mempengaruhi minat berwirausaha seseorang, karena bila kesiapan instrumentasi tersebut sudah terpenuhi maka akan meningkatkan kepercayaan diri seseorang untuk menjadi wirausahawan.

Kebutuhan akan prestasi dapat diartikan sebagai suatu kesatuan watak yang memotivasi seseorang untuk menghadapi tantangan untuk mencapai kesuksesan dan keunggulan. Kebutuhan akan prestasi juga dapat mendorong kemampuan pengambilan keputusan dan kecenderungan untuk mengambil resiko seorang wirausaha (dalam Indarti, 2008). Kebutuhan prestasi mempengaruhi minat berwirausaha seseorang yang ingin mencapai jenjang karir yang diinginkan sesuai dengan kerja keras yang dilakukan.

Agar mahasiswa termotivasi dan mempunyai keinginan berwirausaha dirasakan perlu untuk menganalisis faktor-faktor yang dapat mempengaruhi mahasiswa berkeinginan untuk berwirausaha dengan harapan nantinya dapat menjadi pertimbangan pihak perguruan tinggi dalam mengembangkan mata kuliah khususnya di bidang kewirausahaan. faktor - faktor tersebut yang pertama yaitu keberhasilan diri, kedua yaitu toleransi akan resiko, ketiga yaitu merasakan pekerjaan bebas, keempat kebutuhan akan prestasi, dan yang kelima kesiapan instrumentasi menjadi seorang wirausaha.

\section{RUMUSAN MASALAH}

Berdasarkan latar belakang masalah tersebut, maka yang menjadi rumusan masalah dalam penelitian ini adalah :

a. Bagaimana variabel keberhasilan diri, toleransi akan resiko, kebebasan dalam bekerja, kebutuhan akan prestasi, dan kesiapan instrumentasi secara individual mempengaruhi keinginan mahasiswa untuk menjadi wirausaha.

b. Bagaimana variabel kebebasan dalam bekerja, toleransi akan resiko, keberhasilan diri, kebutuhan akan prestasi, dan kesiapan instrumentasi secara bersama-sama mempengaruhi keinginan mahasiswa menjadi wirausahawan.

\section{TUJUAN PENELITIAN}

Sesuai dengan latar belakang dan rumusan masalah, maka tujuan penelitian ini adalah sebagai berikut :

a. Untuk mengetahui pengaruh variabel keberhasilan diri, toleransi akan resiko, kebebasan dalam bekerja, kebutuhan akan prestasi, dan kesiapan instrumentasi terhadap keinginan mahasiswa Universitas Semaranguntuk menjadi Wirausaha.

b. Untuk mengetahui variabel mana yang paling dominan mempengaruhi keinginan mahasiswa Universitas Semarangmenjadi wirausaha.

\section{KERANGKA PEMIKIRAN}

Adi Tama (2010:106) berpendapat bahwa faktor Keberhasilan diri, aspek ketekunan dan keuletan dalam bekerja nampaknya masih menjadi hal yang paling kurang diperhatikan oleh mahasiswa. Untuk itu dalam banyak hal mengaitkan ketekunan dalam kuliah dan keuletan sebagai bagian awal dari pemupukan jiwa kewirausahaan nampaknya harus menjadi latihan awal mahasiswa, kemudian toleransi akan resiko, kesukaan akan tantangan yang dimiliki mahasiswa dapat memperkecil toleransi resiko yang dipupuk. Untuk itu berbagai pembelajaran diri dalam menemukan tantangan baru harus selalu dimiliki mahasiswa. Dan kebebasan dalam bekerja, aspek pengambilan prakarasa atau inisiatif harus menjadi salah satu upaya untuk memperoleh peluang dan membuat peluang usaha baru. Dengan demikian hal ini mesti dilatih dalam pembelajaran di kampus.

Beberapa penelitian tentang faktor-faktor yang memotivasi mahasiswa berkeinginan menjadi wirausaha yang pernah dilakukan sebelumnya, diantaranya adalah 
penelitian Segal, Borgia and Schoenfeld, (2005:53) membuktikan bahwa toleransi akan risiko, keberhasilan diri dan kebebasan bekerja dirasakan secara signifikan mempengaruhi keinginan untuk berwirausaha. Hasil penelitian juga digambarkan bahwa bila dikombinasikan ketiga variabel tersebut memberikan indikasi kuat terhadap keinginan menjadi seorang pengusaha.

Dari hasil penelitian Indira (2008:68) menunjukkan bahwa Kebutuhan akan prestasi, memiliki pengaruh yang paling signifikan sehingga secara bersama-sama mempengaruhi keinginan mahasiswa untuk berwirausaha.

Selanjutnya didalam penelitian Agustina (2011:71) menunjukkan bahwa Kesiapan Instrumentasi berpengaruh positif dan signifikan terhadap keinginan mahasiswa untuk berwirausaha.

Sedangkan hasil penelitian Adeline (2011:8) menunjukkan bahwa terdapat hubungan yang positif dan signifikan antara keinginan merasakan kebebasan dalam bekerja dengan keinginan untuk berwirausaha, seseorang ingin merasakan kebebasan dalam bekerja atau dengan kata lain tidak dibawah pengawasan. Untuk sebagian orang, kebebasan bekerja akan membuat orang tersebut merasa nyaman. Dengan kenyamanannya tersebut dia akan lebih bisa berkreasi dan lebih produktif dibandingkan dibawah pengawasan.

Didalam penelitian Adi Tama (2010:106) menyatakan bahwa Keberhasilan diri, toleransi akan resiko dan kebebasan dalam pekerjaan memiliki pengaruh yang positif dan signifikan terhadap keinginan mahasiswa untuk menjadi seorang entrepreneur. Karena semakin tinggi kepercayaan diri seorang mahasiswa atas kemampuan dirinya untuk dapat berusaha, maka semakin besar pula keinginan untuk berwirausaha

Hasil penelitian Cokorda Istri Sri Widhari dan I Ketut Suarta (2012:54) menunjukkan bahwa variabel keberhasilan diri, berpengaruh secara positif dan signifikan terhadap keinginan mahasiswa berwirausaha, variabel toleransi akan resiko, berpengaruh secara positif dan signifikan terhadap keinginan mahasiswa berwirausaha, dan kebebasan bekerja berpengaruh secara positif dan signifikan terhadap keinginan mahasiswa berwirausaha.

\section{HIPOTESIS PENELITIAN}

Adapun hipotesis yang dapat diajukan dari kerangka pikiran teoritis tersebut adalah sebagai berikut :

Hipotesis 1 : Keberhasilan diri dari berwirausaha mempengaruhi keinginan mahasiswa untuk menjadi seorang wirausaha.

Hipotesis 2 : Toleransi akan resiko mempengaruhi keinginan mahasiswa untuk menjadi seorang wirausaha.

Hipotesis 3 : Keinginan merasakan kebebasan dalam bekerja mempengaruhi keinginan mahasiswa untuk menjadi seorang wirausaha.

Hipotesis 4 : Kebutuhan akan prestasi mempengaruhi keinginan mahasiswa untuk Menjadi seorang wirausaha.

Hipotesis 5 : Kesiapan Instrumental mempengaruhi keinginan mahasiswa untuk menjadi seorang wirausaha

Hipotesis 6 : Keberhasilan diri, Toleransi akan resiko, Keinginan merasakan kebebasan dalam bekerja, Kebutuhan akan prestasi dan Kesiapan Instrumental secara bersama - sama mempengaruhi keinginan mahasiswa untuk menjadi seorang wirausaha. 


\section{TELAAH PUSTAKA}

Motivasi Wirausaha

Menurut Masrukhin dan Waridin (2003:22) motivasi merupakan faktor psikologis yang menunjukkan minat individu terhadap pekerjaan, rasa puas dan ikut bertanggung jawab terhadap aktivitas atau pekerjaan yang dilakukan. Sedangkan Yohanas (2006) menyatakan motivasi adalah faktor yang kehadirannya dapat menimbulkan kepuasan kerja dan meningkatkan produktivitas atau hasil kerja dan menimbulkan berbagai perilaku manusia.

\section{Dorongan untuk berwirausaha sebagai pilihan karir}

Gilad dan Levine (1986) dalam (Segal, Borgia and Schoenfeld, 2005:44) mengusulkan dua teori yang berkaitan erat dengan motivasi menjadi seorang entrepreneur. Teori "dorongan" dan teori "tarikan". Teori "dorongan" berpendapat bahwa individu didorong ke dalam kepengusahaan oleh dorongan negatif dari luar, seperti ketidakpuasan dalam bekerja, kesulitan dalam menemukan pekerjaan, dan gaji yang tidak memuaskan, atau jadwal kerja yang tidak fleksibel. Teori "tarikan" berpendapat bahwa individu ditarik kedalam aktifitas yang berkaitan dengan pengusaha dalam pencarian kebebasan, pemenuhan diri sendiri, kesejahteraan, dan hasil - hasil lain yang diinginkan.

\section{Keinginan Berwirausaha}

Menurut Urdag (1985:197) intention atau keinginan memiliki persamaan kata dengan rencana, tujuan, harapan, rancangan, arah, atau obyek, dimana adanya keinginan untuk melakukan sesuatu melalui ekspresi diri dan dengan kemandirian. Sedangkan menurut Boyd dan Vozikis (1994), keinginan dibutuhkan berdasarkan bagaimana seseorang menafsirkan lingkungan fisik dan sosial mereka, begitu pula dengan bagaimana mereka mengantisipasi hasil di masa depan dari perilaku mereka.

Suparman (Alma, 2001:17) berpendapat karakteristik seseorang yang mempunyai keinginan wirausaha antara lain yaitu:

- Berpikir teliti dan berpandangan kreatif dengan imajinasi konstruktif,

- Memiliki sikap mental untuk menyerap dan menciptakan kesempatan,

- Membiasakan diribersikap mental positif untuk maju dan selalu bergairah dalam

Setiap pekerjaan,

- Mempunyai insiatif,

- Membiasakan membangun disiplin diri,

- Menguasai salesmanship (kemampuan jual), memiliki kepemimpinan dan mampu memperhitungkan resiko,

- Ulet, tekun, terarah, jujur dan bertanggung jawab.

- Berwatak maju, cerdik dan percaya pada diri sendiri.

\section{Keberhasilan diri dari berwirausaha}

Shapero dan Kruger (2000) menggunakan keberhasilan diri sebagai salah satu wakil dari motivasi untuk menjadi entrepreneur karena mempercayai bahwa orangorang mungkin akan termotivasi untuk menjadi entrepreneur apabila mereka percaya wirausaha memiliki kemungkinan lebih besar untuk berhasil dari pada bekerja untuk orang lain untuk mendapatkan hasil yang berharga. Atkitson (2004) menyatakan bahwa salah satu faktor penting dan menjadi daya penggerak bagi seseorang untuk menjadi entrepreneur adalah keinginannya untuk memenuhi kebutuhannya untuk berhasil serta menjauhi kegagalan. Jika seseorang memiliki kebutuhan tinggi untuk berhasil, maka orang tersebut akan bekerja keras dan tekun belajar. 
Hasil penelitian Segal, Borgia and Schoenfeld, (2005:53) membuktikan bahwa Keberhasilan diri secara signifikan mempengaruhi keinginan untuk berwirausaha. Adi Tama (2010:106) juga menyatakan bahwa Keberhasilan diri memiliki pengaruh yang positif dan signifikan terhadap keinginan mahasiswa untuk menjadi seorang entrepreneur. Karena semakin tinggi kepercayaan diri seorang mahasiswa atas kemampuan dirinya untuk dapat berusaha, maka semakin besar pula keinginan untuk berwirausaha. Dengan demikian berdasarkan temuan-temuan penelitian tersebut dihipotesakan bahwa:

H1 : Keberhasilan diri berpengaruh positif terhadap keinginan menjadi wirausaha

\section{Toleransi akan resiko}

Dalam pengambilan keputusan pelaku bisnis atau seorang entrepreneur sebaiknya mempertimbangkan tingkat toleransi akan adanya resiko. Seorang entrepreneur dapat dikatakan risk averse (menghindari resiko) dimana mereka hanya mau mengambil peluang tanpa resiko, dan seorang entrepreneur dikatakan risk lover (menyukai resiko) dimana mereka mengambil peluang dengan tingkat resiko yang tinggi. Menurut Suryana (2003:14) seorang entrepreneur harus mampu mengambil resiko yang moderat, artinya resiko yang diambil tidak terlalu tinggi dan tidak terlalu rendah. Keberanian menghadapi resiko yang didukung komitmen yang kuat, akan mendorong seorang entrepreneur untuk terus berjuang mencari peluang sampai memperoleh hasil. Hasil-hasil itu harus nyata atau jelas, dan merupakan umpan balik bagi kelancaran kegiatannya. Kemauan dan kemampuan untuk mengambil risiko merupakan salah satu nilai utama dalam berwirausaha. Entrepreneur yang tidak mau mengambil risiko akan sukar memulai atau berinisiatif. Sedangkan Yuyun Wirasasmita (2003:21) berpendapat seorang wirausaha yang berani menanggung risiko adalah orang yang selalu ingin jadi pemenang dan memenangkan dengan cara yang baik.

Cokorda Istri Sri Widhari dan I Ketut Suarta (2012:54) membuktikan bahwa toleransi akan risiko dirasakan secara signifikan mempengaruhi keinginan untuk berwirausaha, demikian pula pada hasil penelitian Adi Tama (2010:106) dan Segal, Borgia and Schoenfeld, (2005:53) didalam penelitiannya juga menunjukkan bahwa variabel toleransi akan resiko, berpengaruh secara positif dan signifikan terhadap keinginan mahasiswa berwirausaha. Hal ini dikarenakan motivasi seseorang untuk menjadi seorang wirausaha dipengaruhi oleh karakteristik individu dimana harus mempunyai rasa tanggung jawab yang tinggi, berani mengambil resiko dan suka tantangan. Dengan demikian,

$\mathrm{H} 2$ : Toleransi akan resiko berpengaruh positif terhadap keinginan mahasiswa menjadi wirausaha

\section{Keinginan merasakan kebebasan dalam bekerja}

Kebebasan untuk menjalankan usaha merupakan keuntungan lain bagi seorang entrepreneur. Hasil survey dalam bisnis berskala kecil tahun 1991 menunjukkan bahwa $38 \%$ dari orang-orang yang meninggalkan pekerjaannya di perusahaan lain karena mereka ingin menjadi bos atas perusahaannya sendiri. Beberapa entrepreneur menggunakan kebebasannya untuk menyusun kehidupan dan perilaku kerja pribadinya secara fleksibel. Kenyataannya banyak seorang entrepreneur tidak mengutamakan fleksibilitas disatu sisi saja. Akan tetapi mereka menghargai kebebasan dalam karir kewirausahaan, seperti mengerjakan urusan mereka dengan cara sendiri, memungut laba sendiri dan mengatur jadwal sendiri (Hendro, 2005:51).

Hal tersebut terbukti dari penelitian Adeline (2011:8) yang menunjukkan bahwa terdapat hubungan yang positif dan signifikan antara keinginan merasakan kebebasan dalam bekerja dengan keinginan untuk berwirausaha, seseorang ingin merasakan 
kebebasan dalam bekerja atau dengan kata lain tidak dibawah pengawasan. Untuk sebagian orang, kebebasan bekerja akan membuat orang tersebut merasa nyaman. Dengan kenyamanannya tersebut dia akan lebih bisa berkreasi dan lebih produktif dibandingkan dibawah pengawasan. Dengan demikian,

H3 : Keinginan merasakan kebebasan dalam bekerja berpengaruh positif terhadap keinginan mahasiswa menjadi wirausaha.

\section{Kebutuhan Akan Prestasi}

Kebutuhan berprestasi menunjukkan keinginan seseorang untuk membuat sesuatu atau bekerja dengan lebih baik, atau lebih cepat dibandingkan dengan prestasi orang lain atau prestasi masa lalunya. Wardoyo (2010:27) berpendapat bahwa Kebutuhan berprestasi berhubungan dengan kecemerlangan yaitu prestasi yang ingin dicapai oleh seseorang yang gigih bekerja atau berusaha untuk mencapai tujuan yang telah ditetapkan. Kebutuhan berprestasi menghubungkan sebuah keinginan untuk menyempurnakan sesuatu yang sulit, untuk mengungguli, dan mengerjakan lebih baik daripada yang lain untuk mencapai sebuah kesadaran prestasi personal (McClelland, 1961).

Dari hasil penelitian Indira (2008:68) menunjukkan bahwa Kebutuhan akan prestasi, memiliki pengaruh yang paling signifikan sehingga secara bersama-sama mempengaruhi keinginan mahasiswa untuk berwirausaha. Karena seseorang yang memiliki kebutuhan berprestasi akan lebih mengejar pekerjaan wirausaha dari pada jenis pekerjaan lain. Dengan demikian,

H4: Kebutuhan akan prestasi berpengaruh positif terhadap keinginan mahasiswa menjadi wirausaha

\section{Kesiapan Instrumentasi}

Ketersediaan modal adalah hal yang sangat penting. Demikian pula ketersediaan sumber daya lainnya, termasuk sumber daya manusia (SDM) dengan pengalaman serta keterampilan yang sesuai, sumber daya informasi seperti sumber data, serta sumber daya infrastruktur seperti lokasi yang tepat. Perhatian media juga penting, khususnya sebagai sarana untuk menerbitkan cerita seputar model peran yang sesuai serta cerita tentang kesuksesan yang diraih (Susanto, 2009:11). Kesiapan instrumentasi ialah tiga faktor lingkungan yang dipercaya mempengaruhi wirausaha yaitu akses mereka kepada modal, informasi dan kualitas jaringan sosial yang dimiliki (Indarti, 2008:18).

hasil penelitian Agustina (2011:71) membuktikan bahwa Kesiapan Instrumentasi berpengaruh positif dan signifikan terhadap keinginan mahasiswa untuk berwirausaha. Karena Kesiapan instrumen yang baik terlihat pada ketersediaan modal, jaringan sosial, dan akses pada informasi yang mendukung semangat kewirausahaan. Dengan demikian dapat dihipotesakan bahwa:

H5 : Kesiapan Instrumentasi berpengaruh positif terhadap keinginan mahasiswa Menjadi wirausaha

\section{METODE PENELITIAN}

Penelitian ini dilakukan pada Mahasiswa Universitas SemarangKalimalang, penelitian dilakukan dengan menyebarkan kuesioner dengan berpedoman pada skala likert dimana setiap alternatif jawaban diberikan skor dengan kriteria 1-5, responden diminta tanggapannya atas pernyataan-pernyataan yang diberikan.

Variabel-variabel yang digunakan pada penelitian ini adalah:

1. Variabel terikat (dependent variabel) yaitu keinginan untuk menjadi wirausaha (Y)

2. Variabel bebas (independent) yaitu $(\mathrm{X})$ yang meliputi : 
a. Keberhasilan diri (X1)

b. Toleransi akan resiko (X2)

c. Keinginan merasakan kebebasan dalam bekerja (X3)

d. Kebutuhan berprestasi (X4)

e. Kesiapan Instrumentasi (X5)

\begin{tabular}{|l|l|}
\hline \multicolumn{2}{|c|}{ Variabel Penelitian dan Indikator Penelitian } \\
\hline Keinginan menjadi Wirausaha (Y) & Percaya diri \\
& Inovatif dan kreatif \\
& Memiliki jiwa kepemimpinan \\
& Efektif dan efisien \\
& Berorientasi pada masa depan \\
\hline \multirow{5}{*}{ Keberhasilan diri (X1) } & Semangat dalam bekerja \\
& Orientasi pada tujuan \\
& Optimis \\
\hline Toleransi akan resiko (X2) & Tekun atau ulet \\
& Kompeten \\
\hline Kebebasan dalam bekerja (X3) & Kolektif \\
& Menyukai tantangan \\
& Sabar \\
& Kontrol diri \\
\hline Kebiapan Instrumen (X5) & Tidak suka diatur \\
& Suka mengambil inisiatif \\
& Keras kepala \\
& Kebebasan pribadi \\
& Bersifat intuisi \\
\hline & Studi dan pekerjaan \\
& Performa Kerja \\
& Tanggung Jawab \\
& Keunggulan Pribadi \\
\hline & Ketersediaan Modal \\
& Informasi \\
& Jaringan Sosial \\
Kemampuan Mengatur Modal
\end{tabular}

\section{Kerangka Konsep Penelitian}

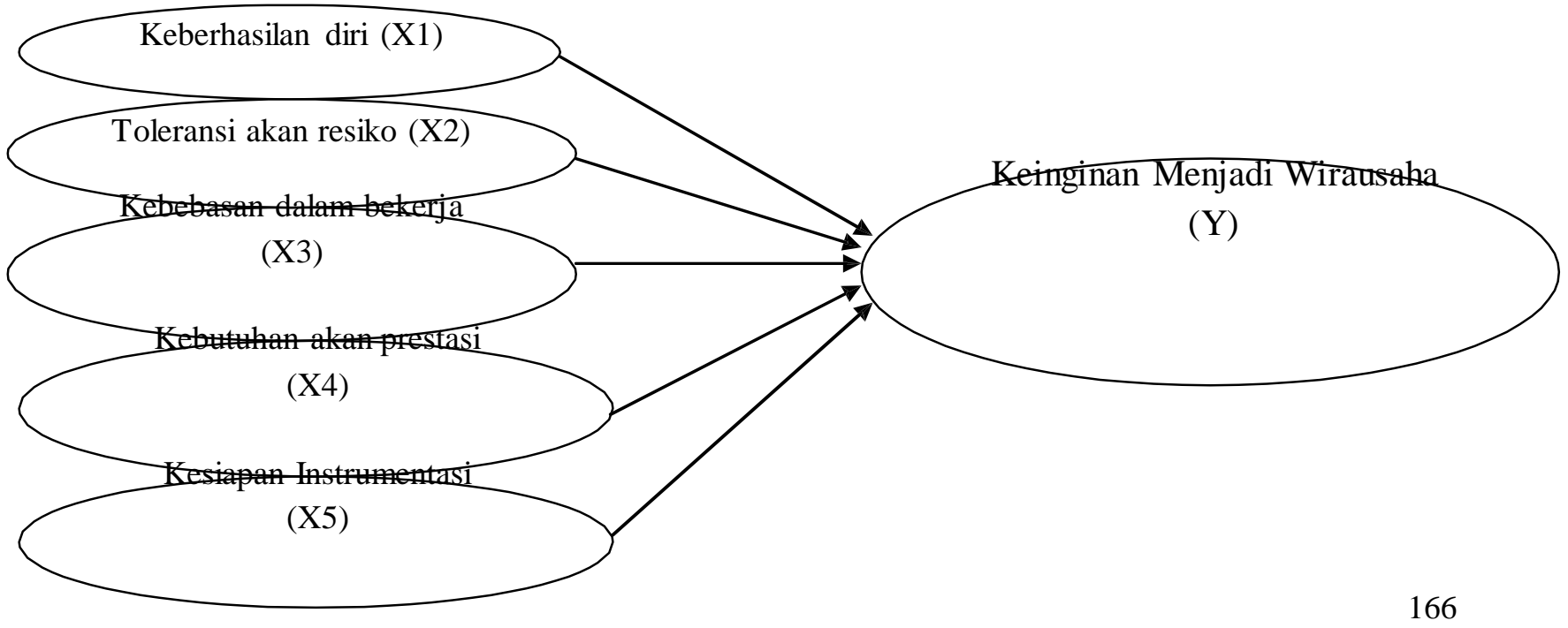

Jurnal Dinamika Sosial Budaya, Volume 18, Nomor 1, Juni 2016 


\section{Alat Analisis \\ Uji Validitas dan Reliabilitas}

Untuk mendukung analisis regresi dilakukan uji validitas dan uji reliabilitas. Uji validitas dalam penelitian ini digunakan untuk menguji kevalidan kuesioner. Valid artinya data-data yang diperoleh dengan penggunaan alat (instrument) dapat menjawab tujuan penelitan. Pengujian validitas adalah pengujian untuk mengetahui kemampuan indikator-indikator suatu konstruk (variabel laten) untuk mengukur konstruk tersebut secara akurat. Variabel indikator memenuhi kriteria valid jika memiliki Corrected ItemTotal Correlation yang bernilai positif. Jika masih terdapat nilai Corrected Item-Total Correlation yang negatif. Maka harus dilakukan pengujian kembali sampai tidak ada Corrected Item-Total Correlation yang bernilai negatif.

Setelah dilakukan uji validitas, hal selanjutnya yang harus dilakukan adalah pengujian reliabilitas. Reliabilitas (keandalan) merupakan ukuran suatu kestabilan dan konsistensi responden dalam menjawab hal-hal yang berkaitan dengan konstrukkonstruk pertanyaan yang merupakan dimensi suatu variabel dan disusun dalam suatu bentuk kuesioner. Reliabilitas yang tinggi menunjukkan bahwa indikator-indikator memiliki konsistensi yang tinggi dalam mengukur variabel laten.

\section{Uji Asumsi Klasik}

Model Regresi Berganda dapat disebut sebagai model yang baik jika model tersebut memenuhi asumsi normalitas data dan bebas dari asumsi klasik, statistik asumsi klasik meliputi:

\section{Uji Normalitas Data}

Uji normalitas data bertujuan untuk menguji salah satu asumsi dasar analisis regresi berganda, yaitu variabel-variabel independent dan dependen harus didistribusikan normal atau mendekati normal. Untuk menguji apakah data-data yang dikumpulkan berdistribusi normal atau tidak dapat dilakukan dengan metode sebagai berikut :

\section{Metode Grafik}

Metode grafik yang handal untuk menguji normalitas data adalah dengan melihat normal probability plot, sehingga hampir semua aplikasi komputer statistik menyediakan fasilitas ini. Normal probability plot adalah membandingkan distribusi komulatif data yang sesungguhnya dengan distribusi komulatif dari distribusi normal (hypotheeical distribution).

Proses uji normalitas data dilakukan dengan memperhatikan penyebaran data (titik) pada Norma P-Plot of Regression Standardized dari variabel terikat (Singgih Santoso, 2000) dimana :

a. Jika data menyebar disekitar garis diagonal, maka model regresi memenuhi asumsi normalitas.

b. Jika data menyebar jauh dari diagonal atau mengikuti garis diagonal, maka model regresi tidak memenuhi asumsi normalitas.

\section{Metode Statistik}

Uji statistik sederhana yang sering digunakan untuk menguji asumsi normalitas adalah dengan menggunakan uji normalitas dari Kolmogorov Smirnov. Metode pengujian normal setidaknya distribusi data dilakukan dengan melihat nilai signifikansi variabel, jika signifikan lebih besar dari alpha 5\% maka menunjukkan distribusi

normal. 


\section{Uji Multikolinieritas}

Uji multikolinearitas dilakukan untuk menguji apakah pada model regresi ditemukan adanya korelasi antar variabel independent. Jika terjadi korelasi, maka dinamakan terdapat problem multikolinearitas. Model regresi yang baik seharusnya tidak terjadi korelasi diantara variabel independent. Uji multikolinearitas pada penelitian dilakukan dengan matriks korelasi. Pengujian ada tidaknya gejala multikolinearitas dilakukan dengan memperhatikan nilai matriks korelasi yang dihasilkan pada saat pengolahan data serta nilai VIF (Variance Inflation Factor) dan Tolerance-nya. Apabila nilai matriks korelasi tidak ada yang lebih besar dari 0,5 maka dapat dikatakan data yang akan dianalisis terlepas dari gejala multikolinearitas. Kemudian apabila nilai VIF berada dibawah 10 dan nilai Tolerance mendekati 1, maka diambil kesimpulan bahwa model regresi tersebut tidak terdapat problem multikolinearitas (Singgih Santoso, 2000).

\section{Uji Heteroskedastisitas}

Uji heteroskedastisitas dilakukan untuk menguji apakah dalam sebuah model regresi terjadi ketidaksamaan varians dari residual dari satu pengamatan ke pengamatan yang lain. Jika varians dari residu atau dari satu pengamatan ke pengamatan yang lain tetap, maka disebut homokedastisitas. Dan jika varians berbeda maka disebut heteroskedastisitas. Model regresi yang baik adalah tidak terjadi heteroskedastisitas (Singgih Santoso, 2000). Salah satu cara untuk mendeteksi heteroskedastisitas adalah dengan melihat grafik scatter plot antara nilai prediksi variable terikat dan nilai residualnya.

\section{Analisis Regresi Linier Berganda}

Regresi dilakukan untuk mengetahui sejauh mana variabel bebas mempengaruhi variabel terikat. Pada regresi berganda terdapat satu variabel terikat dan lebih dari satu variabel bebas. Dalam penelitian ini yang menjadi variabel terikat adalah keinginan mahasiswa untuk menjadi wirausaha, sedangkan yang menjadi variabel bebas adalah keberhasilan diri, toleransi akan resiko, keinginan merasakan kebebasan dalam bekerja, kebutuhan akan prestasi, dan kesiapan instrumentasi.

Model hubungan varibel-variabel tersebut dapat disusun dalam fungsi atau persamaan sebagai berikut:

$$
\mathrm{Y}=\mathrm{a}+\mathrm{b}_{1} \mathrm{X}_{1}+\mathrm{b}_{2} \mathrm{X}_{2}+\mathrm{b}_{3} \mathrm{X}_{3}+\ldots .+\mathrm{b}_{\mathrm{n}} \mathrm{X}_{\mathrm{n}}
$$

$$
\begin{aligned}
& \text { Dimana : } \\
& \text { Y }=\text { Variabel dependen ( keinginan menjadi wirausaha ) } \\
& \text {, }=\text { Variabel independen } \\
& \text { - } \quad \text { (Keberhasilan diri) } \\
& \text { - } \quad \text { (Toleransi akan resiko) } \\
& \text { - } \quad \text { (Kebebasan dalam bekerja) } \\
& \text { - } \quad \text { (Kebutuhan akan prestasi) } \\
& \text { a } \quad=\text { Konstanta } \\
& \text { (Kesiapan Instrumentasi) } \\
& \text {, }=\text { Koefisien }- \text { koefisien regresi }
\end{aligned}
$$

\section{Uji Signifikansi Simultan (Uji-F)}

Uji signifikansi simultan (Uji-F) pada dasarnya menunjukkan apakah semua variabel bebas (X) yang dimasukkan dalam model mempunyai pengaruh secara bersama-sama terhadap variabel terikat (Y). 


$$
\text { Ho: }==\quad=\quad=0
$$

Artinya secara bersama-sama tidak terdapat pengaruh yang positif dari variabel bebas ( ) yaitu berupa Keberhasilan Diri, Toleransi Akan Resiko, Kebebasan Dalam Bekerja, Kebutuhan Akan Prestasi, dan Kesiapan Instrumentasi terhadap Keinginan Mahasiswa Menjadi Wirausaha sebagai variabel terikat (Y).

Ha: $\neq \neq \neq \neq \neq \neq 0$

Artinya secara bersama-sama terdapat pengaruh yang positif dari variabel bebas

( ) yaitu berupa Keberhasilan Diri, Toleransi Akan Resiko, Kebebasan

Dalam Bekerja, Kebutuhan Akan Prestasi, dan Kesiapan Instrumentasi terhadap

Keinginan Mahasiswa Menjadi Wirausaha sebagai variabel terikat (Y).

Kriteria pengambilan keputusan :

Ho di terima jika

pada $\alpha=5 \%$

Ho di tolak jika

$$
\text { pada } \alpha=5 \%
$$

\section{Uji Signifikansi Parsial (Uji-t)}

Uji signifikansi parsial (Uji-t) menunjukkan seberapa besar pengaruh variabel bebas secara individual terhadap variabel terikat.

$$
\text { Ho : }=0
$$

Artinya secara parsial tidak terdapat pengaruh yang positif dan signifikan dari variabel bebas (

) yaitu berupa Keberhasilan Diri, Toleransi Akan Resiko, Kebebasan Dalam Bekerja, Kebutuhan Akan Prestasi, dan Kesiapan Instrumentasi terhadap Keinginan Mahasiswa Menjadi Wirausaha sebagai variabel terikat (Y).

$\mathrm{Ha}: \quad \neq 0$

Artinya secara parsial terdapat pengaruh yang positif dan signifikan dari variabel bebas ( ) yaitu berupa Keberhasilan Diri, Toleransi Akan Resiko, Kebebasan Dalam Bekerja, Kebutuhan Akan Prestasi, dan Kesiapan Instrumentasi terhadap Keinginan Mahasiswa Menjadi Wirausaha sebagai variabel terikat (Y).

Kriteria pengambilan keputusan :

Ho di terima jika

$$
\text { pada } \alpha=5 \%
$$

Ho di tolak jika

$$
\text { pada } \alpha=5 \%
$$

\section{Koefisien determinasi ( )}

Koefisien determinasi ( ) digunakan untuk mengukur seberapa besar kemampuan model dalam menerangkan variabel terikat. Jika semakin besar (mendekati satu), maka dapat dikatakan bahwa pengaruh variabel bebas ( ) adalah besar terhadap variabel terikat (Y). Hal ini berarti model yang digunakan semakin kuat untuk menerangkan pengaruh variabel bebas yang diteliti terhadap variabel terikat. Sebaliknya, jika semakin kecil (mendekati nol), maka dapat dikatakan bahwa pengaruh variabel bebas ( ) adalah kecil terhadap variabel terikat (Y). Hal ini berarti model yang digunakan tidak kuat untuk menerangkan pengaruh variabel bebas yang diteliti terhadap variabel terikat.

\section{HASIL DAN PEMBAHASAN}

Pengujian ada tidaknya gejala multikolinearitas dilakukan dengan memperhatikan nilai VIF (Variance Inflation Factor) dari variabel independen tidak melebihi nilai 10 yaitu keberhasilan diri sebesar 1,867, toleransi akan resiko sebesar 1,182, kebebasan dalam bekerja sebesar 1,747, kebutuhan akan prestasi sebesar 1,085, dan kesiapan instrumentasi sebesar 1,038. Jadi, dapat disimpulkan tidak ada multikolinearitas antar variabel independen dan Tolerance-nya lebih besar dari 0,10 yaitu untuk keberhasilan 
diri sebesar 0,535, untuk toleransi akan resiko sebesar 0,846, untuk kebebasan dalam bekerja sebesar 0,573, untuk kebutuhan akan prestasi sebesar 0,922, dan untuk kesiapan instrumentasi sebesar 0,963. Nilai VIF berada dibawah 10 dan nilai Tolerance mendekati 1, maka diambil kesimpulan bahwa model regresi tersebut tidak terdapat problem multikolinearitas (Singgih Santoso, 2000).

\section{Uji Heteroskedastisitas}

Uji heteroskedastisitas dilakukan dengan cara melihat grafik scatter plot antara nilai prediksi variabel terikat dan nilai residualnya. Untuk mengetahui ada tidaknya gejala heteroskedastisitas dapat dilakukan dengan menggunakan grafik heteroskedastisitas antara nilai prediksi variabel dependen dengan variabel independen. Dari scatterplots dibawah ini terlihat titik-titik menyebar secara acak serta tersebar baik diatas maupun di bawah angka 0 dan sumbu $\mathrm{Y}$, hal ini dapat disimpulkan bahwa tidak terjadi heteroskedastisitas pada model regresi, sehingga model regresi layak untuk digunakan dalam melakukan pengujian. Untuk lebih jelasnya dapat dilihat pada gambar berikut.

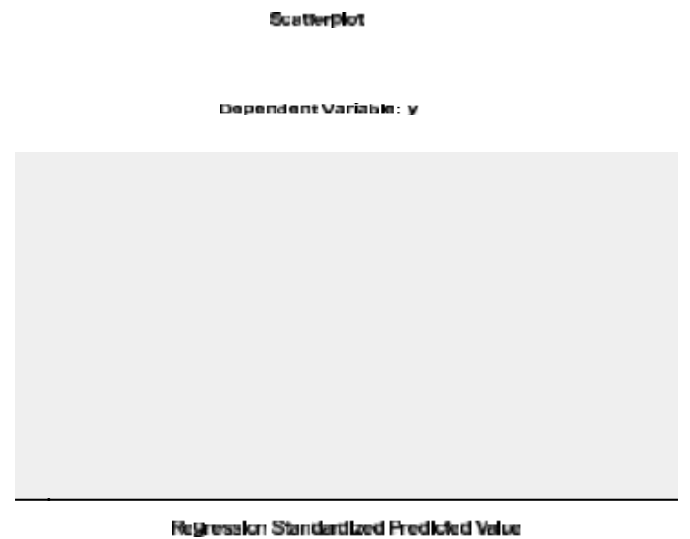

\section{Uji Normalitas Data}

Untuk menguji apakah data-data yang dikumpulkan berdistribusi normal atau tidak dapat dilakukan dengan grafik histogram.

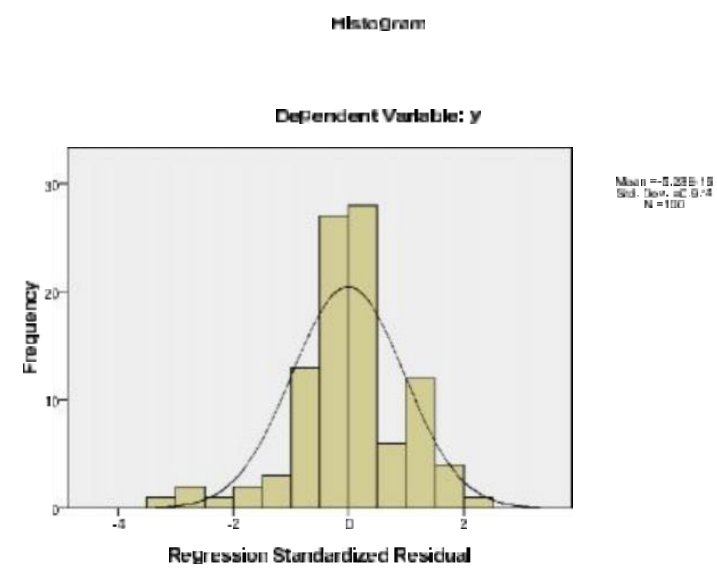

Dari grafik histogram tampak bahwa nilai residual berdistribusi normal dan berbentuk garis simetris tidak miring kekiri maupun kekanan. 


\section{Analisis Regresi Berganda}

Metode analisis data yang dipakai dalam penelitian ini adalah metode analisa kuantitatif. Dimana untuk mencapai tujuan pertama yaitu menganalisis pengaruh keberhasilan diri, toleransi akan resiko, kebebasan dalam bekerja, kebutuhan akan prestasi, dan kesiapan instrumentasi terhadap keinginan mahasiswa berwirausaha adalah dengan menggunakan analisis regresi berganda.

Regresi dilakukan untuk mengetahui sejauh mana variabel bebas mempengaruhi variabel terikat. Pada regresi berganda terdapat satu variabel terikat adalah keinginan mahasiswa untuk menjadi wirausaha, sedangkan yang menjadi variabel bebas adalah keberhasilan diri, toleransi akan resiko, kebebasan dalam bekerja, kebutuhan akan prestasi, dan kesiapan instrumentasi.

Perhitungan statistik dalam analisis regresi linier berganda yang digunakan dalam penelitian ini adalah dengan menggunakan bantuan program komputer SPSS for windows versi 17.0 Hasil pengolahan data dengan menggunakan program SPSS sebagai berikut:

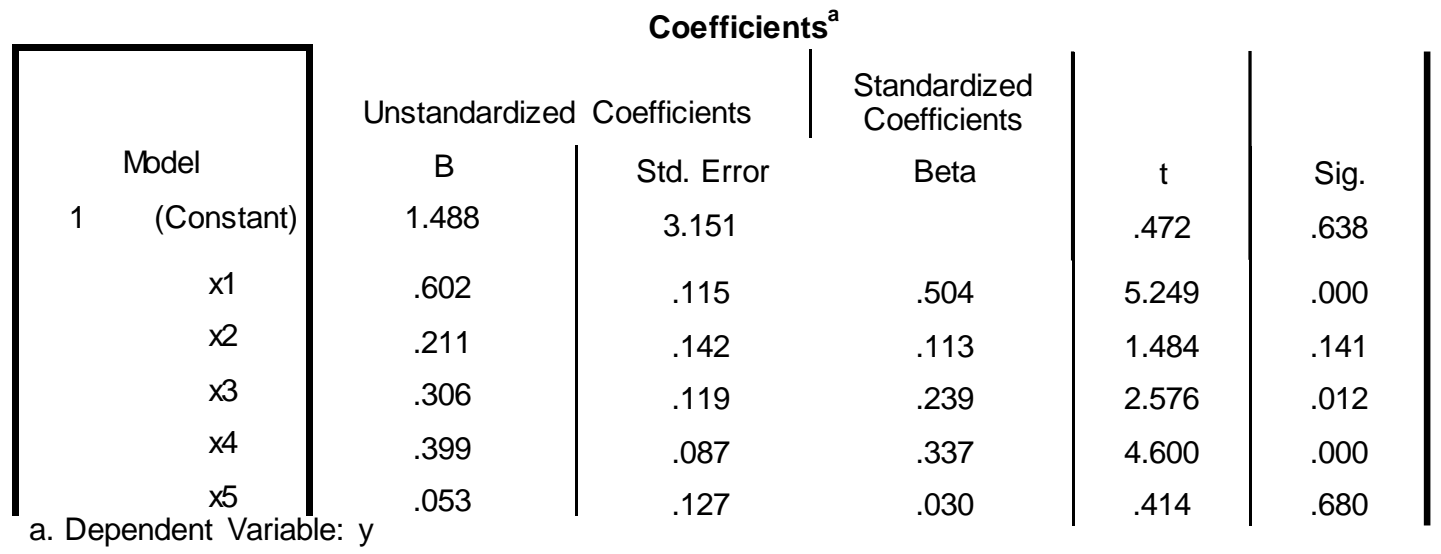

Model persamaan regresi yang dapat dituliskan dari hasil tersebut dalam bentuk persamaan regresi sebagai berikut:

$\mathrm{Y}=1,488+0.602 \mathrm{X} 1+0,211 \mathrm{X} 2+0,306 \mathrm{X} 3+0,399 \mathrm{X} 4+0,053 \mathrm{X} 5+\mathrm{e}$

Diperoleh bahwa kelima variabel tersebut memiliki koefisien regresi dengan arah positif. Hanya saja pada variabel X2 dan X5 yaitu variabel toleransi akan resiko, dan kesiapan instrumentasi tidak berpengaruh signifikan. Hal ini berarti bahwa peningkatan keberhasilan diri, semakin tinggi kebebasan dalam bekerja, dan semakin tinggi kebutuhan akan prestasi akan meningkatkan jiwa seorang wirausaha dalam diri mahasiswa.

\section{Uji Signifikansi Simultan (Uji F)}

Uji F menunjukkan apakah semua variabel independen yang dimasukkan ke dalam model mempunyai pengaruh secara bersama-sama terhadap variabel dependen. Hasil perhitungan uji $\mathrm{F}$ adalah sebagai berikut:

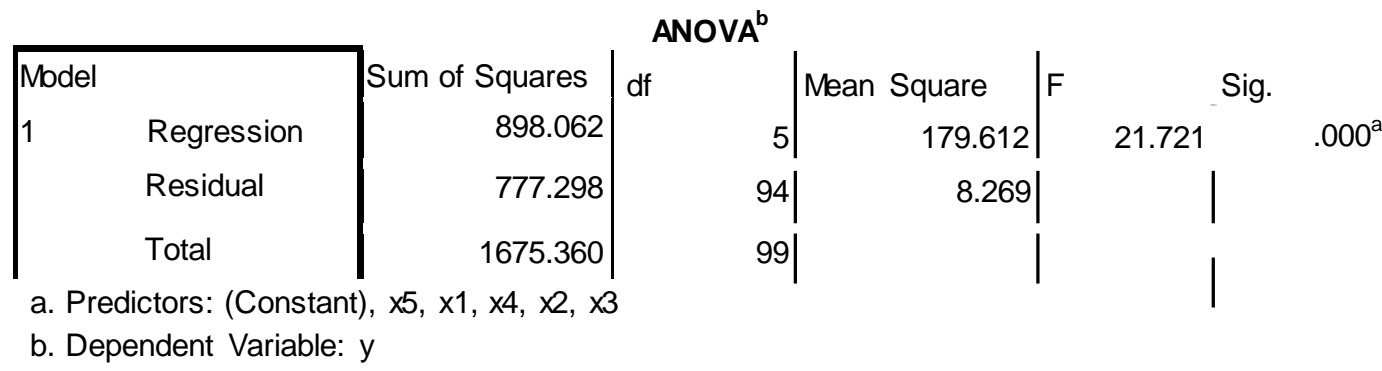


Hasil pengujian berdasarkan uji ANOVA atau uji statistik F, model menunjukkan nilai F sebesar 21,721 dengan probabilitas sebesar 0,000. Nilai signifikansi tersebut lebih kecil dari 0,05. Hal ini berarti bahwa keinginan menjadi wirausaha dapat dijelaskan oleh variabel keberhasilan diri, toleransia akan resiko, kebebasan dalam bekerja, kebutuhan akan prestasi, dan kesiapan instrumentasi.

\section{Uji Signifikansi Pengaruh Parsial (Uji t)}

\begin{tabular}{|c|c|c|c|c|c|c|c|}
\hline & & & Coeffici & & & & \\
\hline & & |Unstandardized & Coefficients & & & & \\
\hline & & B & Std. Error & & & & Sig. \\
\hline 1 & (Constant) & 1.488 & & & & .472 & 638 \\
\hline & $\mathrm{x} 1$ & .602 & & & 504 & 5.249 & .000 \\
\hline & $x 2$ & .211 & & & 113 & 1.484 & .141 \\
\hline & $x 3$ & .306 & & & 239 & 2.576 & .012 \\
\hline & $x 4$ & .399 & & & 337 & 4.600 & .000 \\
\hline & $x 5$ & .053 & & & .030 & .414 & .680 \\
\hline
\end{tabular}

Uji t menunjukkan seberapa jauh pengaruh satu variabel independen secara individual dalam menerangkan variasi variabel dependen. Berdasarkan tabel coefficients dapat diketahui bahwa masing-masing variabel independen keberhasilan diri (X1), kebebasan dalam bekerja (X3), dan kebutuhan akan prestasi (X4) memiliki tingkat signifikansi kurang dari 0,05 . Hal ini berarti masing-masing varibel independen berpengaruh positif dan signifikan terhadap varibel dependen, namun variabel toleransi akan resiko (X2), dan kesiapan instrumentasi (X5) berpengaruh positif namun tidak signifikan. hal ini dikarenakan masih nilai signifikansi lebih dari 0,05.

\section{Koefisien Determinasi (R2)}

Koefisien determinasi mengukur seberapa jauh kemampuan model dalam menerangkan variasi variabel dependen. Berikut ini Tabel koefisien determinasi yang dihasilkan dalam penelitian:

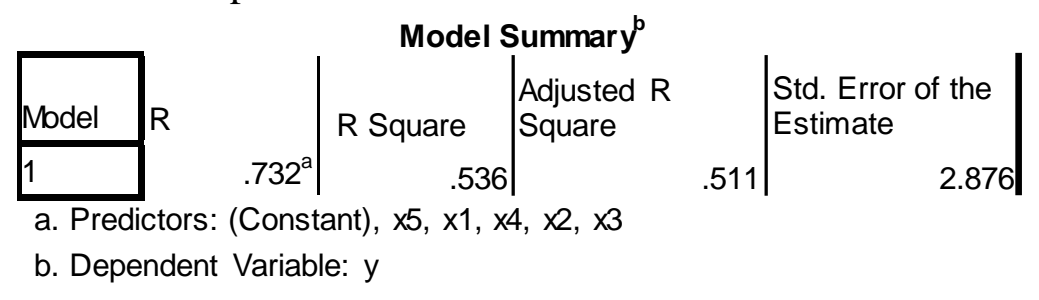

Hasil perhitungan regresi dapat diketahui bahwa koefisien determinasi ( $R$ Square) yang diperoleh sebesar 0,536. Hal ini berarti 53,6\% variabel dependent yaitu keinginan menjadi wirausaha dapat dijelaskan oleh variabel independentnya yaitu keberhasilan diri, toleransi akan risiko kebebasan dalam bekerja, kebutuhan akan prestasi dan kesiapan instumentasi. sedangkan 46,4\% keinginan menjadi wirausaha dapat dijelaskan oleh variabel lainnya yang tidak dimasukkan dalam penelitian ini. 


\section{Pembahasan Hasil Uji Hipotesis}

\section{Pengujian Hipotesis 1}

Berdasarkan pengujian dengan SPSS diperoleh hasil pengujian pengaruh keberhasilan diri terhadap keinginan menjadi wirausaha menunjukkan nilai t sebesar 5,249 dengan probabilitas sebesar 0,000. Nilai signifikansi tersebut lebih kecil dari 0,050 . Hal ini berarti bahwa keberhasilan diri memiliki pengaruh positif yang signifikan terhadap keinginan mahasiswa untuk menjadi seorang wirausaha. Berarti Hipotesis 1 diterima. Hasil hipotesis ini sesuai dengan penelitian sebelumnya yang dilakukan oleh Segal, Borgia and Schoenfeld, (2005:53), Adi Tama (2010:106), Cokorda Istri Sri Widhari dan I Ketut Suarta (2012:54), dan Adeline (2011:8), berdasarkan analisis regresi yang distandarisasi hipotesa pertama yang menyatakan ada pengaruh yang signifikan antara variabel keberhasilan diri terhadap keinginan menjadi wirausaha, terbukti dan hipotesa diterima. Hal ini menunjukkan mahasiswa memiliki semangat bekerja yang tinggi dalam menjalankan bisnisnya dan mempunyai jiwa yang optimis untuk tujuan yang diharapkan untuk masa depan mereka.

\section{Pengujian Hipotesis 2}

Berdasarkan pengujian dengan SPSS diperoleh hasil pengujian pengaruh Toleransi akan risiko terhadap keinginan menjadi wirausaha menunjukkan nilai $\mathrm{t}$ sebesar 1,484 dengan probabilitas sebesar 0,141. Nilai signifikansi tersebut lebih besar dari 0,050 . Hal ini berarti bahwa toleransi akan risiko tidak berpengaruh signifikan terhadap keinginan mahasiswa untuk menjadi seorang wirausaha, Berarti Hipotesis 2 ditolak. Hasil hipotesis ini tidak sesuai dengan penelitian sebelumnya yang dilakukan oleh Segal, Borgia and Schoenfeld, (2005:53), Adi Tama (2010:106), Cokorda Istri Sri Widhari dan I Ketut Suarta (2012:54), dan Adeline (2011:8). Yang menyatakan bahwa variabel toleransi akan resiko, berpengaruh secara positif dan signifikan terhadap keinginan mahasiswa berwirausaha. ini dikarenakan tidak semua mahasiswa menyukai tantangan dan suka mengambil kesempatan-kesempatan yang ada.

\section{Pengujian Hipotesis 3}

Berdasarkan pengujian dengan SPSS diperoleh hasil pengujian pengaruh kebebasan dalam bekerja terhadap keinginan menjadi wirausaha menunjukkan nilai $\mathrm{t}$ sebesar 2,576 dengan probabilitas sebesar 0,012. Nilai signifikansi tersebut lebih kecil dari 0,050 . Hal ini berarti bahwa kebebasan dalam bekerja memiliki pengaruh positif yang signifikan terhadap keinginan mahasiswa untuk menjadi seorang wirausaha. Berarti Hipotesis 3 diterima. Hasil hipotesis ini sesuai dengan penelitian sebelumnya yang dilakukan oleh Cokorda Istri Sri Widhari dan I Ketut Suarta (2012:54), berdasarkan analisis regresi yang distandarisasi hipotesa ketiga yang menyatakan ada pengaruh yang signifikan antara variabel kebebasan dalam bekerja terhadap keinginan menjadi wirausaha, terbukti dan hipotesa diterima. Dengan berwirausaha, mahasiswa nantinya setelah lulus akan dapat menciptakan lapangan pekerjaan dan mempunyai kebebasan dalam memilih pekerjaan yang diinginkan.

\section{Pengujian Hipotesis 4}

Berdasarkan pengujian dengan SPSS diperoleh hasil pengujian pengaruh kebutuhan akan prestasi terhadap keinginan menjadi wirausaha menunjukkan nilai $\mathrm{t}$ sebesar 4,600 dengan probabilitas sebesar 0,000. Nilai signifikansi tersebut lebih kecil dari 0,050 . Hal ini berarti bahwa kebutuhan akan prestasi memiliki pengaruh positif yang signifikan terhadap keinginan mahasiswa untuk menjadi seorang wirausaha. Berarti Hipotesis 4 diterima. Hasil hipotesis ini sesuai dengan penelitian sebelumnya 
yang dilakukan oleh Indira (2008:68), berdasarkan analisis regresi yang distandarisasi hipotesa keempat yang menyatakan ada pengaruh yang signifikan antara variabel kebutuhan akan prestasi terhadap keinginan menjadi wirausaha, terbukti dan hipotesa diterima. Karena seseorang yang memiliki kebutuhan berprestasi akan lebih mengejar pekerjaan wirausaha dari pada jenis pekerjaan lain dan cenderung akan melakukan tugas dengan baik pada tugas-tugas dan pekerjaannya.

\section{Pengujian Hipotesis 5}

Berdasarkan pengujian dengan SPSS diperoleh hasil pengujian pengaruh kesiapan instrumentasi terhadap keinginan menjadi wirausaha menunjukkan nilai $\mathrm{t}$ sebesar 0,414 dengan probabilitas sebesar 0,680. Nilai signifikansi tersebut lebih besar dari 0,050 . Hal ini berarti bahwa kesiapan instrumentasi tidak berpengaruh signifikan terhadap keinginan mahasiswa untuk menjadi seorang wirausaha, Berarti Hipotesis 5 ditolak. Hasil hipotesis ini tidak sesuai dengan penelitian sebelumnya yang dilakukan oleh Agustina (2011:71) yang menyatakan bahwa Kesiapan Instrumentasi berpengaruh positif dan signifikan terhadap keinginan mahasiswa untuk berwirausaha. hal ini dikarenakan tidak semua mahasiswa merasa sudah memiliki kesiapan instrumen yang baik kurangnya ketersediaan modal, informasi dan jaringan sosial yang dimiliki setiap individu perlu dipersiapkan jika berkeinginan menjadi wirausaha.

\section{Pengujian Hipotesis 6}

Berdasarkan pengujian dengan SPSS diperoleh hasil pengujian pengaruh keberhasilan diri, toleransi akan resiko, kebebasan dalam bekerja, kebutuhan akan prestasi dan kesiapan instrumentasi secara bersama-sama mempengaruhi keinginan menjadi wirausaha sebesar 0,000 karena nilai signifikan lebih kecil dari 0,05 maka Hipotesis 6 diterima. Dengan demikian keinginan mahasiswa untuk menjadi seorang wirausaha dapat dimotivasi dengan adanya faktor keberhasilan diri, toleransi akan resiko, kebebasan dalam bekerja, kebutuhan akan prestasi dan kesiapan instrumentasi.

\section{Kesimpulan}

Dari pembahasan yang telah diuraikan, maka dapat ditarik kesimpulan sebagai berikut:

1. Variabel independen (Keberhasilan diri, Toleransi akan resiko, Kebebasan Dalam Bekerja, Kebutuhan akan prestasi, dan Kesiapan Instrumentasi) secara bersamasama memiliki pengaruh positif dan signifikan terhadap Keinginan Mahasiswa Universitas Semarangmenjadi Wirausaha.

2. Variabel independen (Keberhasilan diri, Kebebasan dalam bekerja, dan Kebutuhan akan prestasi) secara parsial atau individu memiliki pengaruh yang positif dan signifikan terhadap Keinginan Mahasiswa Universitas Semarangmenjadi Wirausaha. Sedangkan variabel independen (Toleransi akan resiko, dan Kesiapan instrumentasi) tidak berpengaruh signifikan hal ini dikarenakan masih banyaknya mahasiswa yang belum melakukan kegiatan wirausaha cenderung menghindari resiko dalam pengambilan keputusan, dan masih terbatasnya akses mereka terhadap modal, informasi yang diketahui, dan jaringan sosial yang dimiliki setiap mahasiswa.

3. Faktor Keberhasilan Diri memiliki pengaruh yang paling besar terhadap Keinginan Mahasiswa Universitas Semaranguntuk Menjadi Wirausaha. Hal ini terlihat dari nilai koefisiennya sebesar 0,602 lebih besar dari Toleransi akan resiko $(0,211)$, 
Kebebasan dalam bekerja (0,306), Kebutuhan Akan Prestasi $(0,399)$ dan Kesiapan Instrumen $(0,053)$.

\section{Saran}

Saran-saran yang dapat diberikan sebagai tindak lanjut dari hasil penelitian adalah sebagai berikut :

1. Berkaitan dengan faktor Keberhasilan diri, aspek kompeten dalam bekerja nampaknya masih menjadi hal yang paling kurang diperhatikan oleh mahasiswa. Untuk itu dalam banyak hal mengaitkan kompetensi untuk bersaing dengan orang lain didalam perkuliahan sebagai bagian awal dari pemupukan jiwa kewirausahaan nampaknya harus menjadi latihan awal mahasiswa.

2. Berkaitan dengan toleransi akan resiko, kesukaan dalam mengambil kesempatan-kesempatan yang dimiliki mahasiswa dapat memperkecil toleransi resiko yang dipupuk. Untuk itu berbagai pembelajaran diri dalam mengambil kesempatan-kesempatan yang ada harus selalu dimiliki mahasiswa.

3. Berkaitan dengan kebebasan dalam bekerja, aspek pengambilan prakarsa atau inisiatif harus menjadi salah satu upaya untuk memperoleh peluang dan membuat peluang usaha baru. Dengan demikian hal ini mesti dilatih dalam pembelajaran di kampus.

4. Berkaitan dengan kebutuhan akan prestasi, upaya untuk melakukan yang lebih baik dibandingkan dengan orang lain harus dikembangkan didalam diri mahasiswa sebagai bagian dari pemupukan jiwa kewirausahaan.

5. Berkaitan dengan kesiapan instrumentasi, akses terhadap modal, informasi, dan jaringan sosial yang dimiliki mahasiswa perlu ditingkatkan sebagai upaya untuk membuka peluang usaha bagi mahasiswa. Hal ini dapat dilakukan dengan membuka kerjasama antar mahasiswa, alumni maupun pihak universitas. Agar nantinya para lulusan dapat menyalurkan dan mengembangkan potensi berwirausaha yang ada pada diri mereka.

\section{DAFTAR PUSTAKA}

Alma, Buchari. 2011. Pengantar Bisnis. Alfabeta. Bandung.

Adeline. 2011. Faktor -Faktor yang Mempengaruhi Minat Berwirausaha Budidaya

Lele Sangkuriang. Jurnal Ekonomi Manajemen. Universitas Gunadarma

Agustina, Cynthia. 2011. Intensi Kewirausahaan Mahasiswa : Studi Perbandingan Antara Fakultas Ekonomi dan Fakultas Ilmu Komputer. Skripsi. Bekasi: Universitas Gunadarma

Boyd, N. G., dan Vizikis, G. S. 2014. The influence of self-efficacy in the development of entrepreneurial intentions and actions. Entrepreneurship Theory and Practice, 18, 63-90

Hendro. 2005. How to become a smart entrepreneur and to start a new business. Penerbit Adi. Yogyakarta.

Indira, Christera Kuswahyu. 2012. Student Entrepreneurship Intention: Study of Comparison Between Java and Non Java. Jurnal Manajemen. Fakultas Ekonomi. Universitas

Gunadarma 
Indarti N, 2009. "Intensi Kewirausahaan Mahasiswa: Studi Perbandingan antara Indonesia, Jepang, dan Norwegia". Jurnal Ekonomi dan Bisnis Indonesia. Vol.23, No.4.

Krueger, NF and Shapero, (2010). The cognitive infrastructure of opportunity emergence.Entrepreneurship Theory \& Practice 24: 5-23

Segal, Gerry, Borgia and Jerry Schoenfeld. 2012. The Motivation To Become An Entrepreneur. International Journal of Entrepreneurial Behavior \& Researc. Vol. 11 No1. Emerald Group Publishing Limited. USA.

Singgih Santoso. 2013. Buku Latihan SPSS Statistik Parametik. Jakarta: PT Elex Media Komputindo Gramedia.

Susanto, A.B. 2014. Leadpreneurship. Jakarta: Esensi

Sudjatmoko, Agung, 2014. Cara Cerdas Menjadi Pengusaha Hebat. Jakarta:Visi Media.

Suryana. 2013. Kewirausahaan. Jakarta: Salemba Empat.

Tama, Angki adi. 2010. Analisis Faktor-faktor yang memotivasi mahasiswa berkeinginan menjadi wirausaha. Skripsi. Semarang: Universitas Diponegoro. Semarang

Urdag, Laurence. 2005. The Basic book of Synonyms and Antonyms (new revised ed), United States: Signet

Wardoyo, 2010. Pengaruh Pendidikan Kewirausahaan Terhadap Karakteristik Dan Kompetensi Kewirausahaan Serta Implikasinya Pada Intensi Berwirausaha Mahasiswa. Disertasi. Jakarta. Universitas Gunadarma. Jakarta

Widhari, Cokorda istri sri., dan I ketut suarta. 2012. Analisis Faktor-faktor yang memotivasi mahasiswa berkeinginan menjadi wirausaha. Jurnal Bisnis dan Kewirausahaan. Vol.8 No.1 Maret 2012. Kampus Bukit Jimbaran. Bali.

Yuyun Wirasasmita 2013. Komunikasi Bisnis. Jakarta : PT Gramedia Pustaka Utama 